\title{
PENERAPAN PRAKTEK DAN TEORI AKUNTANSI SYARIAH BERDASARKAN PRINSIP SYARIAH
}

\author{
BimaCinintyaPratama,Inta Gina Setiawiani, Siti Fatimah, Herman Felani \\ UniversitasMuhammadiyahPurwokerto \\ pratamabima@gmail.com
}

\begin{abstract}
Syari'ah accounting is gaining attention, both from practitioners in accounting and from scholars or academics. This paper aims to explain the differences of principles applied to conventional accounting with syari'ah accounting. This paper uses literature review approach. All data and information contained in this paper are obtained from sources such as scientific journals, regulations, and the internet. The method used is descriptive, which describes a condition of implementation of principles adopted by conventional accounting and syari'ah accounting. The findings indicate that the actual accounting syar'iah in many ways, it is better to rely upon in applying accounting processes and financial records of the company.
\end{abstract}

Keywords :Syari'ah accounting, Conventional accounting, Syar'iah accounting principles and Economics

AKUISISI : Jurnal Akuntansi dan Keuangan

Website : http://www.fe.ummetro.ac.id/ejournal/index.php/JA

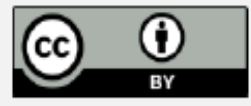

This is an open access article distributed under the terms of the Creative Commons Attribution 4.0 International License, which permits unrestricted use, distribution, and reproduction in any medium, provided the original work is properly cited.

\section{PENDAHULUAN}

\section{A. Latar Belakang}

Ekonomi Islam memiliki pemikiran ilmiah dan koheren yang komprehensif yang berbeda dari ekonomi konvensional. Teori ekonomi Islam mengatakan bahwa "Ekonomi Islam tidak menawarkan kerangka komprehensif untuk ekonomi modern. Ini gagal untuk menyediakan metode analisis yang terdefinisi dengan baik dan operasional", Kuran (1995). Namun, ekonomi konvensional, dengan pendekatan ilmiah dan argumen positifnya telah gagal menyelesaikan masalah ekonomi umat manusia. Dalam wilayah pembangunan ekonomi umat, keberadaan dan kehadiran lembaga bisnis, seperti lembaga keuangan syariah adalah mutlak adanya. Dikarenakan perbankan bertindak sebagai perantara (intermediary) antara unit penawaran (supply) dengan unit permintaan (demand), di sini diperlukan proses pencatatan dan pelaporan semua transaksi dan kegiatan muamalah yang dilakukan di unit bisnis. Oleh karena itu, diperlukan sistem akuntansi yang sesuai (relevan). Sehubungan dengan itu, perlu pula adanya proses akuntansi. Proses akuntansi ini 


\section{PenerapanPraktekdanTeoriAkuntansi}

tidak saja akan mempengaruhi perilaku manajemen, pemegang saham, karyawan, dan masyarakat sekelilingnya, tetapi juga organisasi yang bersangkutan. Munculnya kesan bahwa akuntansi juga memiliki kaitan dengan ideologi sulit untuk diletakkan dan akuntansi seperti yang saat ini diajarkan pada jurusan - jurusan akuntansi di Indonesia, ternyata sangat kuat dipengaruhi oleh kapitalisme. Singkatnya, informasi akuntansi yang kapitalistik akan membentuk jaringan kuasa yang kapitalistik juga. Jaringan inilah yang akhirnya mengikat manusia dalam samsara kapitalisme. Padahal terdapat perbedaan yang sangat besar antara nilai-nilai yang berkembang dalam masyarakat Islam dan barat. Dalam masyarakat Islam terdapat sistem nilai yang melandasi setiap aktivitas masyarakat, baik pribadi maupun komunal. Hal ini tidak ditemukan dalam kehidupan masyarakat barat. Perbedaan dalam budaya dan sistem nilai ini menghasilkan bentuk masyarakat, praktik, serta pola hubungan yang berbeda pula. Tujuan akuntansi syariah adalah terciptanya peradaban bisnis dengan wawasan humanis, emansipatoris, transendental, dan teologis. Dengan akuntansi syariah, realitas sosial yang dibangun mengandung nilai tauhid dan ketundukan kepada ketentuan Allah swt. Seperti yang dikatakan oleh Sardar (1991), "Ini karena, pertama, ekonomi neoklasik, menjadi disiplin positif, tidak memainkan peran aktif dalam mengarahkan atau mengendalikan perilaku manusia atau peristiwa ekonomi. Ini hanya menjelaskan atau merasionalisasi mereka. Kedua, beberapa postulat dasar seperti keegoisan manusia yang inheren, usaha bebas yang tidak diatur, kedaulatan konsumen, kebebasan mutlak untuk mendapatkan, menyelamatkan, menginvestasikan atau membuang serta berperan penting dalam menciptakan berbagai masalah ekonomi.

Solusi untuk masalah ekonomi masa kini memerlukan hal yang lengkap dari kebijaksanaan konvensional kontemporer".Bukan hanya kegagalan untuk memecahkan masalah ekonomi, namun sebenarnya fondasi teori ekonomi akhir-akhir ini menjadi kontroversial. Paradigma neoklasik yang dirayakan sampai pertengahan tahun tujuh puluhan karena "ekonomi" kehilangan semua kemegahannya ketika teori harapan rasional menyingkirkan semua alasan di bawahnya. Sementara akar ilmu ekonomi sudah jelas dikenal dan dipahami oleh para ekonom, itu tidak benar-benar terjadi dengan ekonomi Islam. Akar ekonomi Islam seharusnya, menurut definisi, terletak pada Fiqh. "Ekonomi Islam" sebagai disiplin yang berbeda akan dibenarkan hanya jika kita dapat menunjukkan bahwa literatur Fiqh, yang memberikan pemahaman tentang teks-teks Islam, membawa kita pada akar yang berbeda untuk memahami perilaku ekonomi manusia. Para ekonom yang tertarik pada ekonomi Islam pada umumnya tidak memiliki akses terhadap sumber Fiqh, terutama karena Fiqh adalah ilmu yang luas dan sangat terspesialisasi. Materi yang relevan dengan ekonomi tidak secara eksplisit diidentifikasi dalam ilmu ini. Materi yang mencakup ilmu ini harus dicari dalam literatur Fiqih yang luas. Hal ini dapat menyebabkan kendala serius dalam membangun bangunan ekonomi Islam di atas akarnya sendiri agar berbeda dengan ekonomi konvensional. 


\section{B. Batasan, Perumusan dan Tujuan Masalah}

1. Batasan Masalah

Berdasarkan identifikasi masalah di atas, penulis memfokuskan permasalahan dilihat dari pengertian serta prinsip Akuntansi baik syariah maupun konvensional, prinsip syariah, serta teori dan praktek akuntansi syariah terbentuk sampai dengan perkembangannya sekarang ini di Indonesia.

2. Perumusan Masalah

a. Mengetahui pengertian dan kerangka akuntansi syariah?

b. Bagaimana perbedaan akuntansi syariah dan akuntansi konvensional?

c. Bagaimana teori dan praktek akuntansi syariah terbentuk sampai dengan perkembangannya sekarang ini di Indonesia?

3. Tujuan Masalah

a. Untuk mengetahui pengertian dan kerangka akuntansi syariah.

b. Untuk mengetahui perbedaan akuntansi syariah dan akuntansi konvesional.

c. Untuk mengetahui teori dan praktek akuntansi syariah yang terbentuk sampai dengan perkembangan sekarang ini di Indonesia.

\section{TelaahLiteratur}

\section{A. Definisi Akuntansi Syariah}

Akuntansi Syariah antara lain berhubungan dengan pengakuan, pengukuran, dan pencatatan transaksi dan pengungkapan hak - hak dan kewajiban - kewajubanya secara adil. Konsep akuntansi dalam islam adalah penekanan pada pertangggung jawaban atau accountability berdasar pada $\mathrm{Al}$ Qur'an dalam surat Al baqarah ayat 282. Dalam ayat tersebut disebutkan kewajiban bagi mukmin untuk menulis setiap transaksi yang masih belum tuntas supaya jelas kadarnya, waktunya, dan mudah untuk persaksianya sehingga tidak ragu. Artinya perintah tersebut ditekankan pada kepentingan pertanggungjawaban, agar pihak yang pihak yang terlibat dalam transaksi itu tidak diragukan, tidak menimbulkan konflik dan adil, sehingga perlu para saksi (Danaferus, 2016). Akuntansi syariah merupakan salah satu upaya mendekontruksi akuntansi modern ke dalam bentuk yang humanis dan sarat nilai. Tujuan akuntansi syariah adalah terciptanya peradaban bisnis dengan wawasan humanis, emansipatoris, transendental, dan teleologikal. Konsekuensi ontologis upaya ini adalah bahwa akuntan secara kritis harus mampu membebaskan manusia dari ikatan realitas peradaban, beserta jaringan-jaringan kuasanya, kemudian memberikan atau menciptakan realitas alternatif dengan seperangkat jaringanjaringan kuasa Ilahi yang mengikat manusia dalam hidup sehari-hari (ontologi tauhid), Triyowono dan Grafikin (1996). 


\section{PenerapanPraktekdanTeoriAkuntansi}

\section{B. Prinsip-prinsip Akuntansi Syariah}

Berdasarkan Surat Al Baqarah 282:

1. Pertanggungjawaban (Accountability)

Prinsip pertanggungjawaban (accountability), merupakan konsep yang tidak asing lagi dikalangan masyarakat muslim. Pertanggungjawaban selalu berkaitan dengan konsep amanah. Bagi kaum muslim, persoalan amanah merupakan hasil transaksi manusia dengan Sang Khalik mulai dari alam kandungan.

2. Prinsip Keadilan

Pada konteks akuntansi, menegaskan kata adil dalam ayat 282 surat Al-Baqarah, dilakukan oleh perusahan harus dicatat dengan benar. Misalnya, bila nilai transaksi adalah sebesar Rp. 265 juta, maka akuntan (perusahaan) harus mencatat dengan jumlah yang sama dan sesuai dengan nominal transaksi. Secara sederhana dapat berarti bahwa setiap transaksi yang dengan kata lain tidak ada window dressing dalam praktik akuntansi perusahaan.

3. Prinsip Kebenaran

Prinsip ini sebenarnya tidak dapat dilepaskan dengan prinsip keadilan.Sebagai contoh, dalam akuntansi kita selalu dihadapkan pada masalah pengakuan, pengukuran laporan. Aktivitas ini akan dapat dilakukan dengan baik apabila dilandaskan pada nilai kebenaran. Kebenaran ini akan dapat menciptakan nilai keadilan dalam mengakui, mengukur, dan melaporkan tansaksi-transaksi dalam ekonomi.

\section{Prinsip Dasar Akuntansi Konvensional}

Akuntansi kapitalis dibangun berdasarkan landasan pikir sekuler terkonstruksi sebagai ilmu yang bebas nilai (Value Free), sehingga satu-satunya landasannya adalah rasional tanpa memiliki dimensi teologis ketauhidan serta moral. Akuntansi yang dibangun pada ranah peradaban ekonomi kapitalis lahir sebagai perangkat konstruktif peradaban tersebut. Seluruh dimensi penyajian laporan keuangan selalu mencerminkan kebutuhan dan kepentingan stockholder sesuai dengan filosofi induk yang melahirkannya, hal ini sesuai dengan apa yang dikatakan Karl Max bahwa akuntansi kapitalis hanya merupakan legalisasi kaum kapitalis untuk tetap eksis.

\section{METODOLOGI PENELITIAN}

Penulisan artikel ini dilakukan untuk menemukan rasionalitas dan kebenaran hakikat, pengetahuan dan praktik akuntansi, maka kajian teori kritis akan digunakan, yang penerapannya dilakukan melalui analisis deskriptif. Metode penelitian deskriptif adalah sebuah metode yang berusaha mendeskripsikan, menginterpretasikan sesuatu, misalnya kondisi atau hubungan yang ada, pendapat yang berkembang, proses yang sedang berlangsung, akibat atau efek yang terjadi atau tentang kecenderungan yang sedang berlangsung. Sesuai dengan pendekatan yang digunakan dalam 
BimaCinintyaPratama, dkk...

penelitian ini, maka data yang digunakan diambil dari artikel-artikel dari jurnal ilmiah yang terpercaya, peraturan-peraturan yang berlaku, danpernyataan-pernyataanahli yang relevan. Dengan demikian teknik analisis yang dilakukan adalah teknik analisisisi (content analysis).

\section{PEMBAHASAN}

Pembicaraan mengenai akuntansi Islam haruslah dipahami sebagai sebuah alat yang memiliki orientasi sosial. Sebab akuntansi Islam tidak hanya sebagai alat untuk menterjemahkan fenomena ekonomi dalam bentuk ukuran moneter tetapi juga sebagai suatu metode untuk menjelaskan bagaimana fenomena ekonomi itu berjalan dalam masyarakat Islam. Hal ini tidak sama dengan perbedaan antara akuntansi deskriptif dengan akuntansi normatif. Akuntansi deskriptif ini bertujuan untuk menawarkan akuntansi yang cocok dengan tujuan tertentu. Jika tujuanb erbeda, maka pasti norma juga berbeda. Secara jelas akuntansi Islam yang diterapkan pada lembaga keuangan syariah adalah upaya penerapan akuntansi yang menyangkut masalah ekonomi, masalah politik, dan juga masalah akuntansi itu sendiri. Dengan kata lain, fungsinya sebagai bagian dar isyariah. Dalam kontek situ harus diterima, bahwa akuntansi syariah memainkan peranan untuk menyesuaikan kelompok yang berkepentingan bisnis dalam masyarakat.

\section{Perbedaan Akuntansi Syariah dan Akuntansi Konvensional}

Akuntansi syari'ah dan akuntansi konvensional merupakan sifat akuntansi yang diakui oleh masyarakat ekonomi secara umum. Keduanya merupakan hal yang tidak terpisahkan dari masalah ekonomi dan informasi keuangan suatu perusahaan atau sejenisnya. Perbedaan menurut Husein Syahatah, dalam buku Pokok-Pokok Pikiran Akuntansi Islam, antara lain terdapat pada hal-hal sebagai berikut:

a) Para ahli akuntansi modern berbeda pendapat dalam cara menentukan nilai atau harga untuk melindungi modal pokok, dan juga hingga saat ini apa yang dimaksud dengan modal pokok (kapital) belum ditentukan.

b) Modal dalam konsep Akuntansi Konvensional terbagi menjadi dua bagian, yaitu modal tetap (aktiva tetap) dan modal yang beredar (aktiva lancar), sedangkan di dalam konsep Islam barang-barang pokok dibagi menjadi harta berupa uang (cash) dan harta berupa barang (stock), selanjutnya barang dibagi menjadi barang milik dan barang dagang;

c) Dalam konsep Islam, mata uang seperti emas, perak, dan barang lain yang sama kedudukannya, bukanlah tujuan dari segalanya, melainkan hanya sebagai perantara untuk pengukuran dan penentuan nilai atau harga, atau sebagi sumber harga atau nilai;

d) Konsep konvensional mempraktekan teori pencadangan dan ketelitian dari menanggung semua kerugian dalam perhitungan, serta mengenyampingkan laba yang bersifat mungkin, sedangkan konsep Islam sangat memperhatikan hal itu dengan cara penentuan 
nilai atau harga dengan berdasarkan nilai tukar yang berlaku serta membentuk cadangan untuk kemungkinan bahaya dan resiko;

e) Konsep konvensional menerapkan prinsip laba universal, mencakup laba dagang, modal pokok, transaksi, dan juga uang dari sumber yang haram, sedangkan dalam konsep Islam dibedakan antara laba dari aktivitas pokok dan laba yang berasal dari kapital (modal pokok) dengan yang berasal dari transaksi, juga wajib menjelaskan pendapatan dari sumber yang haram jika ada, dan berusaha menghindari serta menyalurkan pada tempattempat yang telah ditentukan oleh para ulama fiqih. Laba dari sumber yang haram tidak boleh dibagi untuk mitra usaha atau dicampurkan pada pokok modal;

f) Konsep konvensional menerapkan prinsip bahwa laba itu hanya ada ketika adanya jualbeli, sedangkan konsep Islam memakai kaidah bahwa laba itu akan ada ketika adanya perkembangan dan pertambahan pada nilai barang, baik yang telah terjual maupun yang belum. Akan tetapi, jual beli adalah suatu keharusan untuk menyatakan laba, dan laba tidak boleh dibagi sebelum nyata laba itu diperoleh.

g) Komponen laporan keuangan entitas Syariah meliputi neraca, laporan laba rugi, laporan arus kas, laporan perubahan ekuitas, laporan perubahan dana investasi terikat, laporan sumber dan penggunaan dana zakat, laporan sumber dan penggunaan dana qardh dan catatan atas laporan keuangan. Sedangkan komponen laporan keuangan konvensional tidak menyajikan laporan perubahan dana investasi terikat, laporan sumber dan penggunaan dana zakat serta laporan sumber dan penggunaan dana qardh.

\section{Perkembangan Teori \& Praktek Akuntansi Islam}

\section{a. Perkembangan Teori \& Praktek Akuntansi Islam secara Umum}

Realitas akuntansi modern yang dibangun dengan nilai-nilai egoistik, materialistik dan utilitarian, menjadi belenggu bagi manusia modern untuk menemukan jati dirinya dan tuhan. Bagi kalangan masyarakat muslim, Tuhan menjadi tujuan akhir dan menjadi tujuan puncak kehidupan manusia. Akuntansi syari'ah hadir untuk melakukan dekonstruksi terhadap akuntansi modern. Melalui epistemologi berpasangan, akuntansi syari'ah berusaha memberikan kontribusi bagi akuntansi sebagai instrumen bisnis sekaligus menunjang penemuan hakikat diri dan tujuan hidup manusia.

a) Versi Pertama:

Akuntansi syari'ah memformulasikan tujuan dasar laporan keuangannya untuk memberikan informasi dan media untuk akuntabilitas. Informasi yang terdapat dalam akuntansi syari'ah merupakan informasi materi baik mengenai keuangan maupun nonkeuangan, serta informasi nonmateri seperti aktiva mental dan aktiva spiritual. Contoh aktiva spiritual adalah ketakwaan, sementara aktiva mental adalah akhlak yang 
BimaCinintyaPratama, dkk...

baik dari semua jajaran manajemen dan seluruh karyawan. Sebagai media untuk akuntabilitas, akuntansi syari'ah memiliki dua macam akuntabilitas yaitu akuntabilitas horisontal, dan akuntabilitas vertikal. Akuntabilitas horisontal berkaitan dengan akuntabilitas kepada manusia dan alam, sementara akuntabilitas vertikal adalah akuntabilitas kepada Sang Pencipta Alam Semesta.

b) Versi Kedua

Tujuan dasar laporan keuangan syari'ah adalah: memberikan informasi, memberikan rasa damai, kasih dan sayang, serta menstimulasi bangkitnya kesadaran keTuhanan. Ketiga tujuan ini, merefleksikan secara berturut-turut dunia materi, mental, dan spiritual. Tujuan pertama secara khusus hanya menginformasikan dunia materi baik yang bersifat keuangan maupun non keuangan. Tujuan kedua membutuhkan bentuk laporan yang secara khusus menyajikan dunia mental yakni rasa damai, kasih dan sayang.

b. Prinsip Modal Pokok dalam Akuntansi Islam

Diantara tujuan syariat Islam ialah menjaga dan mengembangkannya melalui jalur-jalur yang syar'i, untuk merealisasikan fungsinya dalam kehidupan perekonomian serta membantu memakmurkan bumi dan pengabdian kepada Allah SWT. Sumber-sumber hukum Islam telah mencukup kaidah-kaidah yang mengatur pemeliharaan terhadap modal pokok (kapital). Prinsip-Prinsip Akuntansi pada Modal Pokok yang terpenting diantaranya sebagai berikut.

1. Tamwil dan Syumul (Mengandung Nilai dan Universal) modal itu harus dapat memberikan nilai, yaitu mempunyai nilai tukar di pasar bebas. Bisa saja, modal beda dalam naungan sebuah perusahaan dalam bentuk uang, barang milik, atau barang dagangan selama harta itu masih bisa dinilai dengan uang oleh pakar-pakar yang ahli di bidang itu serta disepakati oleh mitra usaha.

2. Mutaqawwim (Bernilai) Modal itu harus bernilai, artinya dapat dimanfaatkan secara syar'i. Jadi, harta-harta yang tidak mengandung nilai tidak termasuk dalam wilayah akuntansi yang sedang dibicarakan, seperti khamar, daging babi, dan alat-alat perjudian.

3. Penguasaan dan Pemilikan yang Berharga Mal atau harta itu harus dimilki secara sempurna dan dikuasainya sehingga ia dapat memanfaatkannya secara bebas dalam bermuamalah atau bertransaksi. Sebagai contoh, tidak boleh bagi seseorang untuk memulai dengan pihak lain kerjasama dalam uang dan pekerjaan dengan janji membayarkan uang tersebut dikemudian hari atau uang itu masih bersifat utang (dalam jaminan), seperti yang ditegaskan oleh ulama fiqih dalam fiqih syarikah.

4. Keselamatandan Keutuhan Ra,sul-maal Sistem akuntansi Islam menekankan pemeliharan terhadap kapital yang hakiki, seperti yang tergambar dalam sabda Rasul sebagai 
PenerapanPraktekdanTeoriAkuntansi

berikut. "Seorang mukmin itu bagaikan seorang pedagang; dia tidak akan menerima laba sebelum dia mendapatka ra'sul-maalnya (modal). Demikianjuga, seorang mukmin tidak akan mendapatkan amalan-amalan sunnahnya sebelum ia menerima amalan-amalan wajibnya.” (HR Bukhari dan Muslim). Jadi, kalau modal belum dipisahkan dan keuntungan telah dibagi, itu dianggap telah membalikan sebagai modal kepada sipemilik saham. Hal inilah yang banyak menimbulkan masalah dalam perusahaan-perusahaan.

\section{Prinsip Perhitungan Laba dalam Akuntansi Islam}

Diantara tujuan dagang yang terpenting ialah meraih laba, yang merupakan cerminan pertumbuhan harta. Laba ini muncul dari proses pemutaran modal dan pengopersiannya dalam aksi-aksi dagang dan moneter. Islam sangat mendorong pendayagunaan harta/modal yang melarang menyimapnnya sehingga tidak habis sdimakan zakat, sehingga harta itu dapat merealisasikan peranannya dalam aktivitas ekonomi. Di dalam Islam, laba mempunyai pengertian khusus sebagaimana telah dijelaskan oleh ulama-ulama salaf dan khalaf. Dalam bahasa Arab, laba berarti pertumbuhan dalam dagang

\section{Kesimpulandan Saran}

A. Kesimpulan

Akuntansi konvensional yang berkembang hingga saat ini dan yang banyak dipakai para akuntan di dunia terbukti tidak sesuai dengan nilai-nilai islam yang bersumber pada Al Quran dan Al Hadis. Bahkan pada perkembangannya akuntansi konvensional yang bebas nilai ini, yang dilandasi pola berpikir egoistik, materialistik dan utilitarian tidak memiliki kemampuan untuk menjawab persoalan-persoalan akuntansi yang muncul dewasa ini.

Perkembangan dan perubahan bentuk industri tidak diikuti secara pararel oleh ilmu akuntansi konvensional, pencatatan hanya dilakukan pada aktiva berwujud saja, sedangkan industri pada masa kini besar dengan assets berupa aktiva tak berwujud seperti paten, goodwill, lisensi, hak cipta, internet, website, software dan sebagainya. Itulah salah satu keterbatasan akuntansi konvensional pada saat ini, tidak mampu menghitung assets yang diluar kalkulasi material.Dalam sistem tersebut, kegiatan identifikasi, klarifikasi, dan pelaporan dan mengambil keputusan ekonomi harus berdasarkan prinsip akad-akad syari'ah, yaitu tidak mengandung zhulum (Kezaliman), riba, maysir (judi), gharar (penipuan), barang yang haram dan membahayakan.

Dengan sistem yang dianut tersebut, Akuntansi Islam justru pada perkembangannya saat ini menunjukkan kinerja yang lebih baik dari sistem akuntansi lainnya. 
B. Saran

Peran Dewan Pengawas Syariah untuk mengawasi jalanya prinsip akuntansi syariah sesuai tuntunan Al-Quran dan Hadits selain itu harus adanya publikasi terhadap masyarakat mengenai prinsip-prinsip akuntansi syariah yang baik diterapkan dilembaga keuangan. Serta dalam lembaga keuangan syariah informasi yang tersedia harus mampu menggambarkan pencapain tujuan yang ada dan konsistensinya dengan syariat

\section{DAFTAR PUSTAKA}

Danaferus, AnnisaRahmi, Nenengurhasanah, Imaniyati, Neni Sri. (2016). "Prinsip Akuntansi dalam Penyajian Laporan keuangan Neraca pada Baitul Maal Wat Tamwil berdasarkan Peraturan Menteri KUKM No. 14/Per/K.UKM/IV/2015 tentang Akuntansi Usaha Simpan Pinjam dan Pembiayaan Syariah Dihubungkan dengan Prinsip Akuntansi Syariah (Studi Kasus pada BMT Mutiara Insani)”.Prosiding Keuangan dan Perbankan Syariah. Volume 2 Nomor 2.Hlm 535 - 542. ISSN :2460 - 2159.

Kuran, Timur (1995), "Islamic Economics and the Islamic Subeconomy."

Journal of Economic Perspectives, 9 (4), 155-173.

Sardar, Ziauddin (1991), "Islam and Future: Editor's Introduction.” Futures, 23

(3), 223-230 